\title{
Elites in Turkey: Murray Milner's Political Sociology Versus The New Ulemate
}

\author{
Barış Büyükokutan* \\ Koç University
}

\begin{abstract}
This article features an extensive review of Murray Milner, Jr.'s Elites (2015). After summarizing its argument, locating it in debates in political sociology, and highlighting why it matters, I apply the conceptual framework advanced in the book to Turkey. I find that while Milner's framework captures the Turkish case quite well, it cannot account for generous state support of some status elites. I offer a tentative solution to this puzzle by distinguishing between political elites' short- and long-term interests. This shows that Milner's framework should be developed further to better account for multiple and competing interests.
\end{abstract}

Keywords: political sociology, culture, JDP, intellectuals, strategy.

\section{Türkiye'nin Elitleri: Murray Milner'ın Siyaset Sosyolojisi ve Yeni Ulema}

\section{Özet}

Bu makale, Murray Milner, Jr.'ın Elites (2015) isimli kitabının geniş bir değerlendirmesini sunmaktadır. Milner'ın eserini özetleyip siyaset sosyolojisinde durduğu yeri tartıştıktan ve kitabın önemini açıkladıktan sonra, kitapta geliştirilen kavramsal çerçeveyi Türkiye örneğine uygulamaktadır. Milner'ın çerçevesi Türkiye örneğini oldukça başarıyla açıklasa da devletin bazı statü seçkinlerine verdiği cömert destek bu çerçeveye uymamaktadır. Makale, bu durumu siyasi seçkinlerin uzun dönemli ve kısa dönemli çıkarları arasında bir ayrım yaparak açıklamayı önermektedir. Sonuç olarak Milner'ın kavramsal çerçevesinde farklı ve yarışan çıkarların daha iyi kuramsallaştırılması çerçevenin geleceği için uygun olacaktır.

Anahtar Kelimeler: siyaset sosyolojisi, kültür, AK Parti, entelektüeller, strateji.

* Barış Büyükokutan is an Assistant Professor in the Department of Sociology at Koç University, Rumelifeneri Yolu, 34450 Sarıyer, İstanbul, Turkey. E-mail: bbuyukokutan@ku.edu.tr 


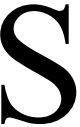
ince the 1960s, scholars have increasingly cast social life as an arena of struggles for various kinds of power, all of which tend to be concentrated in the hands of a small number of people (e.g. Bourdieu 1977, 1984; Domhoff, 1999; Gouldner, 1979; Massey and Denton, 1993; McAdam et al. 2001; Parkin, 1979; Skocpol, 1979; Tilly, 1978; Wright, 1997). In other words, elites exist and they matter. But what exactly are the kinds of power concentrated with the elites? To what degree do elites monopolize power, and how exactly do they do it?

Murray Milner, Jr.'s Elites (2015) is a recent synthesis of these debates. Bringing together insights from Marx, Pareto, Weber, and Bourdieu in a simple but versatile framework, Milner proposes three (and only three) kinds of power to be found everywhere, assigns a category of elites to each kind, and describes each category as being divided along one (and only one) axis: the newcomers versus the entrenched. Non-elites are similarly portrayed as divided into two, so all societies are depicted as consisting of eight kinds of actor in total. Elites is an attempt to understand very different historical developments in terms of the relationships of conflict and cooperation involving these eight actors.

This paper reviews Elites, summarizing it; identifying its contribution; and interpreting the current situation in Turkey as related to it. Of the three near-universals that Milner advances, the first - i.e. that elites demonize unrespectable nonelites to mobilize respectable nonelites - clearly fits the Turkish case. For the second - i.e. that economic elites based in older and newer sectors are in tension - the evidence is ambivalent. However, the third - i.e. that status elites bind the ruled to the rulers - does not seem to apply to Turkey, where political elites largely mobilize the masses themselves.

This raises the question of why political elites spend so many resources in support of a particularly docile and ineffective new ulemate ${ }^{(1)}$ staffing the Directorate of Religious Affairs, religious high schools, and divinity faculties. This new ulemate also seem superfluous for the second role available to them in Milner's scheme, i.e. arbitrating between political and economic elites: Given political elites' remarkable success in concentrating economic as well as political power, there is no room for such an arbiter in the picture. I offer a tentative solution to this puzzle by distinguishing between short- and long-term interests of political elites. As such, I find that the project of which Elites is a part may be improved by taking the notion of multiple and competing interests more seriously than it is now.

\section{Elites: A Unique Synthesis}

Elites has four goals: Subsuming class analysis within an elite-nonelite model; paying greater and more systematic attention to status/cultural/ideological elites than earlier models; systematically including the analysis of nonelites; and avoiding the two pitfalls

(1) I follow Anderson (1977: 376); Runciman (1989: 167); and Bellah and Joas (2012: 332) in translating ulema to English this way. 
of determinism and hyperhistoricism (pp. 134-137). The first two goals locate it in the Weberian tradition, while the latter two express a desire to go beyond the shortcomings of that tradition.

This is therefore not a novel project--Weberian thought has regularly renewed itself during the twentieth century (e.g. Parkin, 1979; Tilly, 1985; Mann, 1986; Gorski, 2011), each time dividing power into class, status, and party (Weber, 1968: 926-939) and each time in response to perceived shortcomings of Weber's own work--e.g. his pessimism regarding the possibility of social change for the better. Milner also operates with these three kinds of power and he too seeks to spin Weberian thought leftwards. In explicit opposition to Foucault, whom he views as collapsing control with socialization and as "lapsing into an empirically untenable and morally debilitating cynicism" (p. 24), he describes power in Weberian terms as the ability to intentionally affect the conduct of other agents (p. 23).

What sets Elites apart is, first, the conceptualization of the three kinds of power based on three sanctions stated more clearly than elsewhere: Economic power is the ability to provide or withhold goods and services; the credible threat of force constitutes political power; and status consists of authoritative expressions of (dis)approval (p. 21). As all three powers tend to be concentrated, but as the ownership of one does not guarantee the ownership of the others, social life is dominated by three partially overlapping elite groups.

Second, Milner systematically distinguishes between groups whose bases of ownership of power differ. These groups are in a fuzzy relationship: sometimes adversarial, sometimes allied, but rarely indifferent. In the economy, new modes of production destabilize older ones (p. 33), but they might eventually be reconciled. Among political elites, kings have to watch out for "raiders, traitors, and invaders" (p. 39) but may sometimes invite them to the polity to keep the peace (p. 32). Among status elites, priests must prevent new prophets from emerging, which requires them to sometimes practice prophecy themselves (p. 38). In all cases, intra-elite cleavage pits incumbents against ambitious upstarts.

Third, in explicit opposition to "elite theory" (i.e. Michels, 1915; Pareto, 1963), nonelites are formally part of the scheme. As Marxists have long known, the consent of the governed is necessary for stable rule and such consent is not always forthcoming. In order to procure consent, political elites typically manipulate nonelites' cultural differences, demonizing noncitizens, slaves, and/or minorities, and presenting themselves as the protectors of "respectable" nonelites. Status elites owe their existence partly to political elites' need for "professional" help here.

There is a more important reason for the existence of status elites, however, and that is the ironing out of the differences between political and economic elites (p. 26). As merchants have few reasons to trust kings and vice versa, there is room for impartial arbiters who will mediate between the two groups. Religious clergy, conservative philosophers, neoliberal economists, and "public intellectuals" specialize in this role. Status elites come in three varieties. 
Status elites proper such as military heroes, athletes, and celebrities lead by example. A subset of status elites in the broader sense, cultural elites such as writers and artists lead by producing texts and text-like objects that circulate broadly. A subset of cultural elites ranging from Plato and Luther to Marx leads by making programmatic statements on the good life; these are ideological elites.

This clear grounding of status as a form of power in a specific sanction is the first reason why Elites is worth one's time. In Weber's work as in his followers', the notion of status remains unclear, sometimes equated with honor, elsewhere with prestige, but rarely settled in a formal definition.

It could be argued that Milner's formulation is little more than Bourdieu's work on cultural capital, but there is a clear difference; that is the second reason why Elites matters. While for Bourdieu cultural capital, institutionalized in universities, embodied in tastes, and objectified in diplomas, is a source of power in itself, Milner argues, convincingly, that for these to actually produce power, the actor wielding them must have public visibility (p. 36). Impeccable credentials and refined tastes do not powerful actors make: actors with such credentials and tastes must take the additional, risky step of coming forward with their strong opinions.

The implications of this difference are profound: For Milner, the typical status elite is not so much the poet but the celebrity, and the vaunted figure of the "public intellectual" itself denotes a subset of floozy celebrityhood instead of evoking images of hard work in pursuit of difficult truths. For the public intellectual to be powerful, his/ her discourse must be unequivocal, easily intelligible, and emotionally relatable. No "corporatism of the universal" (Bourdieu, 1996: 337-348) here.

Still, these differences should not be exaggerated. Milner takes the dynamic between priests and prophets, first theorized by Weber and made into the basis of field theory (see Bourdieu, 1985) by Bourdieu, to be characteristic of all status elites. The legitimating function they serve means that all status elites, including the most secular subtypes, play the role of the priest. Precisely in order to be credible in this role, however, they must sometimes pass as prophets - they must manage to seem more thoroughly otherworldly than the typical priest and challenge some practices associated with economic and political elites (p. 38): If status elites are seen to always take the side of the powerful, they will lose the influence they have over nonelites and thus become less useful to political elites.

The final reason why Elites deserves scholarly attention is its prescience. In his analysis of the United States (pp. 86-133), Milner shows that the two major political parties had been unpopular for a long while, making them vulnerable to hostile takeovers such as the ones attempted by Bernie Sanders and Trump. His description of the American politician as a hybrid of the celebrity and the fundraiser (p. 96) indicates why Trump succeeded while Sanders failed. Added to these new features of the American political life, there is the near-universal strategy of all political elites according to Milner, used expertly by the Trump campaign: relentless scapegoating of ethnic and religious minorities to mobilize nonelite whites. That political elites demonize unrespectable nonelites in order to gain the good graces of respectable nonelites is the first of the three hypotheses that emerge from Milner's interpretation of his three cases (p. 137). 
The other two hypotheses concern the role, described above, that status elites play in justifying political elites to nonelites and the tension between old and new modes of production (pp. 137-138). In Athens, Milner writes, the landed aristocracy was at some point joined by merchants, mine owners, and manufacturers. While aristocrats tended to support oligarchic coups, "new money" was for the most part in favor of the expansion of the democracy (pp. 80-81). Similarly, in the United States, Milner takes the "new class" of symbol processors and the "old class" based in manufacturing to be in tension. While he is not the first to make this point, two things make his claim interesting: First, Milner treats symbol producers as an insurgent economic elite rather than as an intellectual force as some prominent work on intellectuals (e.g. Bell, 1973; Gouldner, 1979; Konrad and Szelenyi, 1979; Szelenyi, 1982) used to do. Second, while the Democratic-leaning Silicon Valley type is a caricature, the parallels between that caricature's struggle with Republican fast-food tycoons on one hand and Athenian new men's struggle with the aristocracy on the other are plainly impressive.

\section{Extending the Argument: Turkey's Elites}

So far so good -- Elites is an important book with interesting theses. But how well do these theses fare empirically? That question is not easily answered by simply evaluating the cases offered in the book--Elites illustrates hypotheses rather than testing them. Its real challenge lies in cases for which it is not clear from the outset that the three theses apply.

One of those cases may be contemporary Turkey. Unlike Milner's own cases, it is a Muslim-majority country in the modern world, and it has often been argued that as a political force Islam is distinct from other religions. Turkey is also, unlike all three of Milner's cases, not the leading power in its neighborhood, which might make for a different set of relationships among the eight actors in the scheme. The rest of this paper is therefore devoted to deploying Milner's lenses on contemporary Turkey.

\section{Political and Economic Elites: Party over Class}

Milner finds that, of the three kinds of elite, one is usually dominant. ${ }^{(2)}$ For Turkey, this would arguably be political elites of the governing Justice and Development Party (JDP), especially those closest to its leader, the president. As a sign of this, The Koçs and the Sabancis, the two wealthiest families, are famously subject to intense scrutiny by state inspectors but they never escalate tensions. ${ }^{(3)}$ Newer, Islamic money is to some extent the product of Islamist politics in the first place (Buğra and Savaşkan, 2014).

Another sign of JDP's power is the difficulty of the second largest party in parliament - Republican People's Party (RPP) - to attain more than $25 \%$ of votes after 15 years of JDP rule. The role of political counterelite - the "raiders, traitors, and invaders"

(2) Brahmin priests, rhetores politicians, and the wealthiest capitalists occupy this position in ancient India, classical Athens, and contemporary United States respectively.

(3) For example, on July 24, 2013, inspectors from the Ministry of Finance raided Tüpraş, OPET, Aygaz and Shell-Turcas, all Koçcontrolled firms, for, among other things, violating the tax code. This was swiftly followed by a 400-million-lira fine imposed by the Turkish Competition Authority on Tüpraş, the largest industrial facility in Turkey. The fine was paid in full within days. 
above -thus arguably falls to a motley crew consisting of Fethullah Gülen, the PKK, the former Mayor of Şişli Mustafa Sarıül, and the nationalist politician Meral Akşener as well as RPP leadership. These actors are at least as much in conflict with one another as they are with JDP.

While political elites have survived many challenges to their rule since day one, however, they may still be in an unenviable position. The near-total concentration of power at the presidential level (Bekdil, 2017; Özdikmenli and Oval1, 2014; Sarfati, 2017) means that the principal/agent problem (Adams, 2005; Coleman, 1990; Eisenhardt, 1989; Olson, 1971) and factional infighting may prevent effective rule, giving counterelites opportunities to exploit.

When it comes to economic elites, the two distinct groups Milner makes much of are not to be easily found in Turkey because capitalists tend to invest in old and new sectors alike as a strategy of risk minimization. The oldest conglomerates, controlled by "secular" money, are not only in manufacturing and construction but also in IT-related sectors. ${ }^{(4)}$ Pious families that have prospered under JDP rule, such as the Ülkers, seem to have followed the same route. ${ }^{(5)}$ Nevertheless, Milner's scheme cannot yet be discarded here, as there is a small number of entrepreneurs who owe their success mainly to the work they do in digitized sectors. ${ }^{(6)}$ It is yet to be seen how they will handle growth.

\section{The Puzzle of Status Elites}

As in the United States, celebrities play political roles. Ever present on television and Twitter, uncredentialled status elites cut closely to the role of the priest-sports commentator Ridvan Dilmen, FC Barcelona midfielder Arda Turan, and actor Murat Boz ran a voluntary campaign in support of the expansion of the president's powers in the run-up to the April 2017 constitutional referendum. As Milner's framework expects, a smaller number of their peers, e.g. the singer Sila Gençosmanoğlu and the actor Halit Ergenç, nonetheless play the role of the otherworldly renouncer.

The contrast between priest-like and prophet-like actors is also visible among cultural and ideological elites, but among cultural elites, prophets may have the upper hand. The Nobel laureate Orhan Pamuk, like the late great Yaşar Kemal, frequently speaks against the president's agenda and the most prestigious universities feature more signatories of the anti-government Academics for Peace petition than of the pro-government Academics for Turkey petition. This is not much of a puzzle, however, as it can be explained by the fact that Turkey's cultural institutions are largely products of the late Ottoman and early Republican periods_-JDP has not had the time to develop institutions of the same caliber.

(4) The Koç family owns Inventram, which focuses on technology commercialization and patent investment; Bilkom, which bills itself "Turkey's digital life coach;" and Koç Sistem, which focuses, among other things, on cloud computing, big data analytics, and digital security. The Zorlu family, who started in textiles, launched the electronics giant Vestel as early as 1984.

(5) The Ülkers started in food production, but they have since diversified into personal care items, packaging, and industrial minerals. Through Gözde Girişim, their venture capital initiative, they have, since 2014, been in control of Penta, a technology distributor.

(6) Examples include Nevzat Aydın, who developed and sold yemeksepeti.com for USD 589 million, and the Akgirays, whose centerpiece is the electronics chain Bimeks. 
In any case, the priestly posture is widespread among ideological elites, so Milner's expectations are for the most part met. Ideological elites include columnists of progovernment dailies and conservative academics in provincial universities, but arguably the central component is a new ulemate--men (and some women) trained in religious high schools and/or divinity faculties. Especially important are those in charge of the Directorate of Religious Affairs (the Diyanet), which appoints imams to Turkey's tens of thousands of mosques and, in coordination with the most prestigious divinity faculties, from which its own top ranks tend to be drawn, oversees the activities of religious high schools. Conservative columnists and academics are largely the product of this establishment, which started during the anticommunist 1940s but came nowhere near its current stature until the 1980s and especially until the rise of the JDP--hence the term "new" ulemate.

These high priests, however, do not seem to play the role Milner reserves for them. As I explained in the previous section, tensions between Turkey's economic and political elites are less marked than elsewhere due to the overwhelming dominance of political elites. With such a lopsided relationship, whatever differences the two groups have are resolved less in accordance with compromises formulated by impartial arbiters and more in ways political elites dictate. In any case, it is not clear that the new ulemate can play the role of the impartial arbiter given that, unlike all the status elites Milner examines, most of its members are on the public payroll. Turkey's priests thus have to find other ways to gain a place at the table.

In the past, one could argue, they would do this by helping political elites keep respectable nonelites' support. However, in Turkey respectable nonelites are increasingly mobilized directly by political elites--often by the president himself. ${ }^{(7)}$ The domestic "enemies" that threaten respectable nonelites and push them towards political elites are numerous, ranging from the secular middle-class demonstrator and the followers of Fethullah Gülen to sympathizers of the Kurdish movement. All such figures are routinely denounced as the fifth column of Western imperialism in the pro-government news media. It is possible that this is orchestrated directly by the staff of the president, with conservative academics, columnists, and clerics following rather than leading the way.

The ineffectiveness of the new ulemate in mobilizing the masses is also at least partly due to the fact that they are dependent on the state for their paychecks. The lazy bureaucrat who clocks out not one minute later than 5 PM may be a caricature, but in the case of the new ulemate, it may have some truth. And even if it does not, it is hard for a state employee to present herself/himself as an independent voice unless she/he is speaking against political elites just as the new ulemate cannot mediate between economic and political elites, its exhortations to obey legitimate authority may sound self-serving and disingenuous to some nonelites.

(7) "Through the effective use of television and the social media, Erdoğan manages to reach out to the masses in a permanent campaign mode. He not only campaigns during the election season but throughout the year to maintain the unmediated linkages between him and his followers." Selçuk 2016:577. 
Here, then, is the question: Why does the new ulemate have so much power? Since 2002, the budget of the Diyanet has swelled; ${ }^{(8)}$ the number of students attending religious high schools has increased from 71,100 to 870,$000 ;{ }^{(9)}$ and the number of divinity faculties has gone from twenty-one to more than seventy, ${ }^{(10)}$ all in spite of apparently declining need for their services. Moreover, the performance of the new ulemate has been underwhelming. Turkey's mosques are, for political elites, to this day not sufficiently packed. ${ }^{(1)}$ Religious high schools are, in spite of generous financial support, performing very badly at the centralized university entrance exams. ${ }^{(12)}$ Given looming economic difficulties, the government might want to divert the enormous resources of the new ulemate elsewhere, but that is not happening.

Why not? Perhaps miscalculation on the part of political elites is the reason. It could be argued that Turkey's political elites underestimate their hold on respectable nonelites and thus feel the need to prop up an ideological establishment whose impotence escapes them. Given the record of the JDP, however, this is not very convincing: If anything, the president and his inner circle tend to overestimate their influence on the population, as their incredulity to the results of the elections of June 7, 2015 indicates. $^{(13)}$

Or it could be the structure of political elites. Knowing that the top-heavy organization of the regime breeds intense jockeying for position and observing that jockeying has become too transparent, the leaders of the party may view the new ulemate as a backup source of legitimacy. That too is unconvincing, however. There is no evidence that either the Diyanet or divinity professoriate are less subject to factionalism and infighting -- indeed, their poor performance can be construed as a sign of their divisions. ${ }^{(14)}$

The fickle support of respectable nonelites. A more plausible account of the power of the new ulemate emerges from the investigation of respectable nonelites, i.e. Sunni Muslim Turkish speakers. ${ }^{(15)}$ Unrespectables include everybody else, most importantly Kurds and Alevis. The revolt of these two groups under the leadership of secular Kurds almost dethroned political elites in June 2015. In a textbook example of the usefulness of Milner's framework, political elites ratcheted up their attacks on the figure of the simultaneously Kurdish and Alevi terrorist, reconsolidating the Sunni Turkish vote in the repeat election of November 2015.

(8) In 2006, the Diyanet's budget consisted of TL 1,452,773,000; for 2015 this figure was up to TL 6,037,744,000 (http://odatv. com/diyanetin-gozunu-toprak-doyursun-0503161200.html).

(9) https://www.birgun.net/haber-detay/13-yilda-1-5-milyon-imam-hatipli-yarattilar-112709.html

(10) http://www.hurriyet.com.tr/ilahiyat-fakultesi-sayisi-artiyor-40112156

(11) Responding to the calls to convert Hagia Sophia, a museum since 1934, back to a mosque, on June 6, 2014, the president instructed the faithful to first fill currently available mosques to capacity.

(12) In 2017, of all 222,925 graduates of religious high schools, only about 40,000 were admitted to four-year colleges. Their success rate, at less than 1 in 5, is thus lower than the success rate of all Turkish high schools (approx. 208,000 out of 960,000). See https://tr.sputniknews.com/turkiye/201708101029635107-imam-hatip-mezun-lys/

(13) President Erdoğan, who rarely fails to make a daily appearance on Turkish TV, was noticeably absent from it from June 7 to June 11

(14) The rumor is that the rivalry between the two top divinity faculties, those of Ankara and Marmara universities, is more than merely academic or religious. See http://www.turkishnews.com/tr/content/2010/07/27/diyanet-universitesine-mutacirektor/27/.

(15) An additional requirement concerns sexuality -- the respectable Turkish citizen is as straight as an arrow. 
This shows that political elites of Turkey cannot take for granted their hold on respectable nonelites. The latter can be rallied by raising the specter of terror and separatism, but their attention to these issues is fickle -- constantly affected by economic woes, middle- and lower middle-class Sunni Turks may always need to be "reminded" of the dangers of prioritizing the prosperity of the nation over its unity.

The support of respectable nonelites being so fickle, political elites may understand that they cannot focus on replacing the new ulemate with a group more to their liking. As the short term dominates their calculations, there may not be much they can do to improve the performance of their cultural henchmen other than supporting them even more generously.

\section{Discussion: Elites, Time and Strategy}

If theory's job is to provide researchers and commentators with sensitizing concepts, Elites is good theory: Its concepts sensitize to three kinds of power and two styles of their ownership, which, together with the distinction between respectable and unrespectable nonelites, turn out to be quite illuminating for the Turkish case.

Yet ideological elites, whose discussion distinguishes Elites from similar attempts to theorize power, do not play the two roles assigned to them in Turkey. My explanation of this puzzle begins by considering the conflict between short- and long-term interests of political elites. In this account, the fickleness of nonelite support and the state of the economy force political elites to operate in the short term, giving the new ulemate a new lease on life.

Recall that I justified using Turkey as a further test case by indicating that it is a peripheral power with a Muslim majority. The divergence I traced in political elites' interests is most probably not due to Islam -- it is rooted in the fluctuations of the economy and in second- and third-grade powers' difficulty in smoothing out those fluctuations. Milner's project will thus benefit from focusing on such polities and comparing them to others.

There is of course the question of whether the inability of political elites to master the economy and thus be forced to deal with nonelites themselves applies only to cases like Turkey. The concept of the permanent campaign was, after all, first proposed to account for U.S. politics (see Blumenthal, 1982), and Donald Trump may constitute its best example yet. I cannot answer that question here, but fortunately the way to do it is the same as what I propose: A more systematic comparison of "stronger" and "weaker" states. 


\section{References}

Adams, J. (2005). The Familial State: Ruling Families and Merchant Capitalism in Early Modern Europe. Ithaca: Cornell University Press.

Anderson, P. (1977). Lineages of the Absolutist State. London: N.L.B.

Bekdil, B. (2017). “Turkey's Slide into Authoritarianism,” Middle East Quarterly, 24(1): 1-9.

Bell, D. (1973). The Coming of Post-Industrial Society: A Venture in Social Forecasting. New York: Basic Books

Bellah, R.N. and Joas, H. (2012). The Axial Age and Its Consequences. Cambridge, Mass.: Harvard University Press.

Blumenthal, S. (1982). The Permanent Campaign. New York: Simon and Schuster.

Bourdieu, P. (1977). Outline of a Theory of Practice. Cambridge, U.K.: Cambridge University Press.

------; (1984). Distinction: A Social Critique of the Judgement of Taste. Cambridge, Mass.: Harvard University Press.

------, (1985). "The Genesis of the Concepts of Habitus and Field," Sociocriticism, 2(2): 11-24.

------, (1996). The Rules of Art: Genesis and Structure of the Literary Field. Stanford: Stanford University Press.

Buğra, A. and Savaşkan, O. (2014). New Capitalism in Turkey: The Relationship between Politics, Religion and Business. Edward Elgar Publishing.

Coleman, J.S. (1990). Foundations of Social Theory. Cambridge, Mass.: Harvard University Press.

Domhoff, G.W. (1999). Who Rules America 2000. New York: Simon \& Schuster.

Eisenhardt, K.M. (1989). “Agency Theory: An Assessment and Review,” Academy of Management Review, 14(1): 57-74.

Gorski, P.S. (2011). The Protestant Ethic Revisited. Philadelphia: Temple University Press. 
Gouldner, A.W. (1979). The Future of Intellectuals and the Rise of the New Class. New York: Seabury.

Konrad, G., and Szelenyi, I. (1979). The Intellectuals on the Road to Class Power. New York: Harcourt Brace Jovanovich.

Mann, M. (1986). The Sources of Social Power. Cambridge; New York: Cambridge University Press.

Massey, D.S., and Denton, N.A. (1993). American Apartheid: Segregation and the Making of the Underclass. Cambridge, Mass.: Harvard University Press.

McAdam, D., Tarrow, S., and Tilly, C. (2001). Dynamics of Contention. New York: Cambridge University Press.

Michels, R. (1915). Political Parties: A Sociological Study of the Oligarchical Tendencies of Modern Democracy. New York: Hearst's International Library.

Milner, M. (2015). Elites: A General Model. Cambridge, UK; Malden, Mass.: Polity Press.

Olson, M. (1971). The Logic of Collective Action: Public Goods and the Theory of Groups. Cambridge, Mass.: Harvard University Press.

Özdikmenli, I., and Oval1, S. (2014). "A Success Story or a Flawed Example? The Anatomy of the Turkish Model for the Middle East," New Perspectives on Turkey, 51: 5-33.

Pareto, V. (1963). The Mind and Society: A Treatise on General Sociology. New York: Dover.

Parkin, F. (1979). Marxism and Class Theory: A Bourgeois Critique. London: Tavistock.

Runciman, W.G. (1989). A Treatise on Social Theory. Cambridge, U.K.: Cambridge University Press.

Sarfati, Y. (2017). "How Turkey's Slide to Authoritarianism Defies Modernization Theory," Turkish Studies, 18(3): 395-415.

Selçuk, O. (2016). "Strong Presidents and Weak Institutions: Populism in Turkey, Venezuela and Ecuador," Southeast European and Black Sea Studies, 16(4): 571-589.

Skocpol, T. (1979). States and Social Revolutions: A Comparative Analysis of France, Russia, and China. Cambridge: Cambridge University Press. 
Streeck, W. (2014). Buying Time: The Delayed Crisis of Democratic Capitalism. Brooklyn, N.Y.: Verso.

------, (2016). How Will Capitalism End? Essays on a Failing System. London: Verso. Szelenyi, I. (1982). "The Intelligentsia in the Class Structure of State-Socialist Societies," American Journal of Sociology, 88: 287-326.

Tilly, C. (1978). From Mobilization to Revolution. Reading, Mass.: Addison-Wesley.

------, (1985). "War Making and State Making as Organized Crime,” in C. Besteman (ed.) Violence: A Reader: 35-60. New York: Palgrave Macmillan

Tuğal, C. (2009). Passive Revolution: Absorbing the Islamic Challenge to Capitalism. Stanford: Stanford University Press.

------, (2016). The Fall of the Turkish Model: How the Arab Uprisings Brought down Islamic Liberalism. London; New York: Verso.

Weber, M. (1968). Economy and Society: An Outline of Interpretive Sociology. New York: Bedminster Press.

Wright, E.O. (1997). Class Counts: Comparative Studies in Class Analysis. Cambridge, U.K.: New York: Cambridge University Press. 